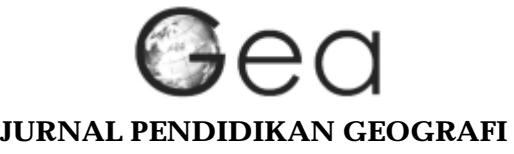

\title{
PERANAN PEM BELAJARAN GEOGRAFI DALAM MEMAHAMI WILAYAH BENCANA DI KOTA BENGKULU
}

\author{
Fevi Wira Citra \\ Universitas Prof Dr Hazairin, SH. Jl. Ahmad Yani No. 1 Bengkulu \\ email: wo_antik@yahoo.co.id
}

\begin{abstract}
ABSTRAK
Bengkulu berada pada jalur patahan sumatera, termasuk rawan bencana gempa. Berada pada pesisir pantai pulau Sumatera.Pendidikan geografi bergerak pada ranah pengetahuan, kecakapan, perilaku untuk membentuk pengalaman peserta didik yang berwawasan kemampuan mitigasi bencana. Untuk melihat pemahaman wilayah bencana yang dimiliki oleh peserta didik. Penel iti mengambil judul "peranan pembel ajaran geografi dalam memahami wilayah bencana di Kota Bengkulu".Penelitian ini menggunakan metode survey.Pengolahan data menggunakan korelasi dan regresi kemudian hasilnya dipaparkan secara deskriptif.Tingkat pemahaman mengenai wilayah bencana hanya $13,93 \%$ peserta didik yang tahu bahwa wilayah yang didiaminya adalah wilayah rawan bencana. Hubungan antara pembelajaran geografi terhadap pemahaman wilayah bencana peserta didik tidak ada hubungan.Perubahan pembelajaran geografi dalam materi mengenai bencana. Proses pembelajaran menggunakan teori konstrutivistik dan model pembelajaran simulasi yang dapat meningkatkan pemahaman peserta didik.
\end{abstract}

Kata kunci : Pemahaman, pembelajaran Geografi, wilayah bencana

\section{PENDAHULUAN}

\section{Latar Belakang M asalah}

Provinsi Bengkulu berada pada jalur patahan sumatera adalah kabupaten kota yang termasuk rawan bencana gempa dan tsunami. Kondisi alam di kota Bengkulu yang secara geografis berada pada pesisir pantai pulau Sumatera menghadap barat daya Samudera Hindia. Kondisi kota Bengkulu saat ini berpotensi menyebabkan timbulnya resiko terjadinya beragam bencana yang dipicu oleh kejadian alam dan ulah manusia. Kota Bengkulu adalah salah satu dari eman puluh tujuh kelurahan yang rawan terhadap bencana.Kota Bengkulu memiliki relief permukaan tanah yang bergelombang, terdiri dari dataran pantai dan daerah berbukit-bukit serta beberapa tempat terdapat cekungan al ur sungai kecil.

Letak Kota Bengkulu berada pada pertemuan lempeng tektonik Samudera H india dan lempeng tektonik Asia menyebabkan Kota Bengkulu dalam beberapa tahun terakhir sering dilanda gempa tektonik (Stasiun Klimatologi Bengkulu, 2008). Gempa bumi sering melanda Bengkulu, padatanggal 4Juni 2000 gempa bumi dengan kekuatan 8 skala Richter menimbulkan bencana paling besar di Bengkulu. Berdasarkan catatan sejarah, bencana gempa juga pernah terjadi pada tahun 1833,1914, 1940, dan1980. Pada tahun 2007 terjadi lagi gempa yang cukup besar di Kota Bengkulu yaitu 7,9 
skala Richter. Jumlah gempa yang terjadi selama tahun 2007 tercatat sebanyak 61 kali (Stasiun Klimatologi Bengkulu, 2008).

Dari kondisi alamitu, di Propinsi Bengkulu yang sering terjadi bencana alam maka diperlukan sosialisasi mitigasi bencana dalam memahami wilayah bencana.Mitigasi (mitigate) berati tindakan-tindakan untuk mengurangi bahaya supaya kerugian dapat diperkecil.Mitigasi meliputi aktivitas dan tindakan-tindakan perlindungan yang dapat diawali dari persiapan sebelum bencana itu berlangsung, menilai bahaya bencana, penanggulangan bencana, berupa penyelamatan, rehabilitasi dan relokasi.Menurut Keputusan Menteri Dalam Negeri RI No. 131Tahun 2003, mitigasi atau penjinakan adalah upaya dan kegiatan yang dilakukan untuk mengurangi dan memperkecil akibatakibatyang ditimbulkan ol eh bencana, yang meliputi kesiapsiagaan, kewaspadaan dan berbagai kemampuan sedangkan dalam undang-undang No 24 tahun 2007 dikatakan bahwa mitigasi bencana adalah serangkaian upaya untuk mengurangi resiko bencana, baik melalui pembangunan fisik maupun penyadaran dan peningkatan kemampuan menghadapi ancaman bencana. Tindakan dari mitigasi terdiri dari mitigasi structural adalah tindakan untuk mengurangi atau menghindari kemungkinan dampak bencana secara fisik. Contoh tindakan mitigasi struktural adalah pembangunan rumah tahan gempa, pembangunan infrastruktur, pembangunan tanggul di bantaran sungai, dan lain sebagainya; dan mitigasi non struktural adalah tindakan terkait kebijakan, pembangunan kepedulian, pengembangan pengetahuan, komitmen publik, serta pelaksanaan metode dan operasional, termasuk mekanisme partisipatif dan penyebarluasan informasi, yang dilakukan untuk mengurangi resiko terkait dampak bencana. Mitigasi merupakan tindakan yang paling efisien untuk mengurangi dampak yang ditimbulkan oleh terjadinya bencana.Kesadaran warga tentang mitigasi bencana sangat penting. Hal ini didasarkan pada pendekatan dalam manajemen bencana yang salah satu prinsipnya adalah pengembangan kemampuan manusia.

Dari pembelajaran mitigasi bencana diharapkan peserta didik memiliki tingkat kesiapsiagaan yang tinggi terhadap bencana alam yang dapat muncul sewaktu-waktu. Kesiapsiagaan itu sendiri diharapkan akan dapat disadari oleh diri sendiri dan pada gilirannya akan disampaikan kepada orang-orang terdekat terutama keluarga dan kepada orang-orang yang berada di sekitar lingkungan tempat tinggal peserta didik.

Di mana seharusnya pembelajaran geografi itu mampu mewadahi fenomena "kebencanaan". Kalau saja Pembelajaran Geografi sudah meaningfull, mungkin saja peristiwa surutnya air laut ketika akan terjadi tsunami di NAD, penduduk itu tidak malah berhamburan menuju ke arah laut untuk mengambil ikan yang terdampar, tetapi akan berusaha untuk menyelamatkan diri mencari daerah yang relatif aman. Jadi pendidikan kebencanaan dan mitigasi bencana, harus merupakan bagian integral dari pembelajaran geografi. Para peserta didik dan masyarakatpadaumumnyaharusdibuat sadar akangeografi, melalui pembelajaran geografi yang meaningfull. Tingkat sadar akan geografi yang tinggi diharapkan akan dapat membangun kesadaran terhadap kondisi diri dan lingkungannya yang setiap saat sensitif dengan kebencanaan.

A tas dasar pemikiran di atas, maka penulis akan melakukan survei untuk mel ihat tingkat pemahaman peserta didik tentang rawan bencana. Kemampuan pemahaman adalah sesuatu hal yang penting dalam pemahaman tentang mitigasi bencana.M enurut penulis dalam pelajaran geografi di tingkat sekolah agar diperoleh hasil yang lebih baik dalam melihat pemahaman. 


\section{Rumusan Masalah}

Bertolak dari latar belakang penelitian diidentifikasi rumusan masalah sebagaiberikut : 1) Sejauh mana pengaruh pemahaman peserta didik tentang kondisi wilayah rawan bencana di Kota Bengkulu? 2) A dakah hubungan pembel ajaran geografi dengan tingkat pemahaman peserta didik tentang wilayah bencana di Kota Bengkulu? dan 3) Adakah hubungan tingkat pemahaman wilayah bencana dengan kesiapsiagaan peserta didik dalam mitigasi bencana di Kota Bengkulu?

\section{METODE PENELITIAN}

Pendekatan penelitian ini menggunakan metode penelitian survey. Menurut Singarimbun (1992:1) bahwa penelitian survey adalah “penelitian yang mengambil sampel dari satu populasi dan menggunakan kuesioner/ angket dan test sebagai alat pengumpulandatayangpokok". Datadalampenelitian ini dikumpulkan menggunakan kuesioner/ angket. Pengolahan data yang dilakukan dengan menggunakan cara korelasi dan regresi Setelah hasil pengolahan data diperoleh kemudian hasilnya dipaparkan secara deskriptif.

Populasi survei dalam penelitian ini adalah peserta didik di SMA kelasX (sepuluh) di Kota Bengkulu. SMA yang dijadikan populasi SMA/ MA N egeri maupun SMA/ MA Swasta.Jumah keseluruhan SMA/ MA yang ada di Kota Bengkulu adalah 29. Setelah di Random maka didapat 4 sekolah yang menjadi sampel penelitian yaitu SMAN 1, SMAN 4, SMA Pembangunan dan SMA Muhammadiyah 4. Jumlah sampel adalah 122 peserta didik dari 4 sekolah.

\section{HASIL DAN PEMBAHASAN}

\section{Tingkat Pemahaman Peserta Didik}

Pemahaman peserta didik tentang wilayah bencana di lihat dengan menggunakan soal tentang mitigasi bencana.Soal yang diberikan kepada peserta didik sebanyak 30 soal objektif.Soal dihitung nilai skor hasil jawaban soal setiap peserta didik di mana skor yang diberikan adalah berskala 1-100. Hasil dari pengolahan datanilaipemahaman wilayah bencana dengan sampel 122 peserta didik diperoleh perhitungan skor terendah 17 dan tertinggi yang diperoleh peserta didik 63, simpangan baku 9.901, dan varian 98,030 .

Nilai yang diperoleh oleh peserta didik ditentukan interval sehingga setiap nilai yang didapat oleh setiap peserta didik masuk pada setiap kategori tingkat pemahaman berdasarkan interval yang sudah ditentukan. Hasil pemahaman mitigasi peserta didik ini diperoleh dari total keseluruhan 122 jumlah peserta didik dengan 4 sekolah yang menjadi sampel. Hasilnya adalah : Pemahaman sangat kurang 23,7\%, Pemahamanan kurang 20,5\%, Pemahaman cukup 45,9\%, Pemahaman baik 9,9\%. Kondisi nyata yang ada di Kota Bengkulu di mana peserta didik hanya dengan persentase tertinggi yaitu 45, 9 \% berada pada kondisi cukup.Melihat kondisi topografi yang ada di Bengkulu seharusnya peserta didik memiliki tingkat pemahaman wilayah yang baik.

\section{Kondisi Pembelajaran Geografi}

Untuk mengetahui kondisi pembelajaran geografi yang terjadi di Kota Bengkulu dilakukan dengan menggunakan angket.Di mana angket berisi tentang sumber belajar peserta didik dan kondisi pembelajaran yang terjadi di kelas terutama tentang materi 
gempa.Data hasil angket peserta didik terhadap pembelajaran geografi didapat dari hasil skor interval dari setiap jawaban peserta didik di mana menggunakan empat interval yaitu dari 1-4dengan juml ah pertanyan padaangket adalah 30. Skor maksimal untuk setiap peserta didik adalah 120 dan dengan skor terendah yaitu 30 .

$\mathrm{H}$ asil dari pengolahan datanilai hasil pembelajaran geografi pada wilayah bencana di empatSMA di KotaBengkulu dengan sampel 122pesertadidik diperoleh perhitungan skor terendah 38 dan skor tertinggi 74 dari angket peserta didik, simpangan baku8,312, dan varian nilai 69,081 peserta didik. Hasil pembelajaran geografi peserta didik ini diperoleh dari 122 jumlah peserta didik yang menjadi sampeladalah : Pemahaman sangat kurang 10,6\%, Pemahamanan kurang 35,2\%, Pemahaman cukup 39,6\% dan Pemahaman baik $14,6 \%$.

\section{Uji Regresi Pembelajaran G eografi dengan Pemahaman Wilayah Bencana}

Uji regresi dilakukan pada 122 peserta didik dengan mengacu pada nilai angket pembelajaran geografi dan nilai pemahaman wilayah bencana yang diperoleh peserta didik dari 30 soal. Pengujian yang dilakukan dengan menggunakan regresi. Dari pengujian regresi dapat dikatakan bahwa rata-rata pembelajaran geografi yang terjadi di Bengkulu adalah 55,90\% dan pemahaman tentang wilayah bencana pada 122 peserta didik yang ada di Bengkulu hanya sebesar 41,58\%. Sedangkan hasil keofisien determinasi memperlihatkan sebesar 0,003 dari koefisien determinasi dapat dikatakan bahwa pembelajaran geografi hanya berpengaruh sebesar 0,03\% terhadap pemahaman wilayah bencana dari 122 peserta didik yang menjadi sampel. Dapat dikatakan pengaruh antara keduanya lemah atau tidak ada hubungan, penilaian ini diambil berdasarkan ketentuan di mana nilai keofisien determinasi hanya berkisar pada angka 0 sampai 1 , jika semakin kecil angka koefisien determinasi maka semakin lemah hubungan kedua variabel.

Mengetahui apakah model regresi bisa dipakai untuk memprediksi pembelajaran geografi berpengaruh terhadap pemahaman wilayah bencana dapat digunakan uji Anova atau uji $F$ test. Dari uji Anova atau $F$ test, didapat $F$ hitung 0,333 dengan probabilitas 0,565, jauh lebih besar dari 0,05, ini berarti model regresi pemahaman wilayah bencana dengan pembelajaran geografi bisa dipakai untuk memprediksi tingkat pemahaman peserta didik.

Selanjutnya dilakukan uji coefficient atau uji beta untuk melihat seberapa besar pengaruh yang dimiliki oleh kedua variabel. Nilai konstan sebesar 54,06, nilai B untuk pemahaman wilayah bencana sebesar 0,044 serta nilai $t_{\text {itung }} 16,532$ dan tingkat signifikansi 0,000 sehingga didapat persamaan regresi sederhana yaitu $Y=a+b X=$ $54,06+0,044 X$, dari persamaan ini dapat dikatakan bahwa pengaruh yang dimiliki antara pembelajaran geografi dengan pemahaman wilayah bencanapada peserta didik hanya sebesar 0,044 .

\section{Uji Korrelasi Pembelajaran G eografi dengan Pemahaman Wilayah Bencana}

Pada bagian ini disajikan korelasi antara pembelajaran geografi dengan pemahaman wilayah bencana nilai kedua variabel. Uji correlasi dilakukan pada 122 peserta didik dengan mengacu pada nilai angket pembelajaran geografi dan nilai pemahaman wilayah bencana yang diperoleh peserta didik dari soal. Pengujian yang dilakukan dengan menggunakan correlasi memperlihatkan bahwa dengan jumlah responden sebanyak 122 peserta didik, rata-rata pemahaman wilayah bencana sebesar 41,58 dengan standar deviasi 9,901. Sedangkan pembelajaran geografi dengan rata- 
rata 55,90 dan standar deviasi 8,312.

Selanjutnya dari hasil correlasi dilihat hubungan antara kedua variabel. Hasil keofisien correlasi pearson antara pemahaman wilayah bencana dan pembelajaran geografi. Nilai yang diperoleh adalah sebesar 0,053 berarti tidak ada hubungan yang cukup kuat antara variabel pembelajaran geografi dengan pemahaman wilayah bencana yang dimiliki oleh peserta didik dan dilihat juga dari hasil signifikansi yang lebih besar dari 0,05 yaitu sebesar 0,565 Nilai koefisien siginfikansi pada pemahaman wilayah bencana dan pembelajaran geografi adalah 0,565 (berasal dari 0,282×0,282), Nilai 0,565 bahwa $56,5 \%$ bisa dijelaskan oleh variabel penelitian. Sedangkan sisanya pada kedua variabel $(100 \%-56,5 \%=43,5 \%)$ dijelaskan oleh faktor lain.

\section{Pembahasan Hasil Penelitian}

Penelitian yang dilakukan untuk melihat pemahaman peserta didik di Kota Bengkulu tentang wilayah bencana menggunakan Sampel peserta didik sebanyak 122 dengan 4 sekolah yang menjadi sampel. Hasil yang diperoleh tentang pemahaman wilayah bencana adalah di mana hanya 12 peserta didik yang memiliki pemahaman yang baik tentang wilayah bencana, 36 peserta didik yang memiliki pemahaman cukup tentang wilayah bencana, 45 peserta didik yang memiliki pemahaman kurang dan 29 peserta didik yang memiliki pemahaman sangat kurang.

Kondisi yang terjadi peserta didik berada pada kondisi di mana pemahaman yang dimiliki pada posisi kurang.Kondisi yang sebenarnya tidak seharusnya terjadi karena peserta didik tinggal di wilayah rawan bencana. Tiga dari sekolah yang menjadi sampel penelitian berada pada posisi yang berbahaya yaitu berada dekat dengan wilayah pantai, seperti pada SM AN 1 di mana posisi sekolah yang sangat dekat dengan pantai dan berada pada jalur sesar aktif, tetapi tingkat pemahaman mitigasinya begitu sangat kurang dan ditambah lagi dengan kondisi pembalajaran geografi yang begitu buruk karena guru di SMAN 1 hanya memberikan tugas yaitu berupa LKS kepada peserta didik tanpa memberikan pemantapan materi terlebih dahulu, suatu kondisi yang diakibatkan karena rendahnya kualitas guru dalam mengajar. Kondisi seperti ini yang menyebabkan salah satu faktor pendukung peserta didik tidak mengetahui bahwa wilayah yang mereka tinggali adalah wilayah rawan bencana.

Sedangkan untuk melihat dari tingkat pemahaman mengenai wilayah bencan di Kota Bengkulu dapat di lihat dari soal no 29 dari total 30 soal, di mana pada soal no 29 menanyakan tentang wilayah kota Bengkulu yang dilalui oleh jalur sesar aktif. Dari 122 peserta didik yang menjadi sampel hanya sebanyak 17 peserta didik yang dapat menjawab dengan benar, hanya sekitar $13,93 \%$ peserta didik yang benar-benar tahu dengan baik bahwa wilayah yang didiaminya adalah wilayah rawan bencana dan $86,07 \%$ menjawab salah. Pemahaman yang begitu sangat kurang dimiliki peserta didik ini sungguh sangat mengkhawatirkan dengan kondisi alam yang dimiliki oleh Kota Bengkulu yaitu berupa jajaran pantai sepanjang Kota Bengkulu dan tepat berada pada pertemuan lempeng tektonik Samudera Hindia dan lempeng tektonik Asia dan beberapa lokasi di Kota Bengkulu yang tepat dilalui oleh jalur sesar aktif sehingga berpotensi sangat besar untuk mengalami kerusakan baik secara sarana fisik maupun ancama korban jiwa dan juga terhadap terjadinya tsunami ketika gempa yang terjadi pusatnya berlokasi di laut.

Pada soal dan angket yang diberikan kepada peserta didik untuk melihat ada hubungan antara pembelajaran geografi yang ada di Kota Bengkulu berpengaruh terhadap pemahaman wilayah bencana peserta didik dapat dikatakan bahwa tingkat 
pemahaman wilayah bencana yang dimiliki oleh peserta didik tidak ada hubungan pada proses pembelajaran geografi. Terlihat dari hasil perhitungan di mana nilai $\mathrm{R}_{\text {square }}$ sebesar 0,003 di mana nilai $R$ lebih kecil dari 0 dan hanya sebesar 9,9\% peserta didik yang memahami tentang wilayah bencana dengan baik. Karena pada pelaksanaan pembelajaran geografi ditemukan bahwa materi gempatidak benar-benar disampaikan secara maksimal oleh guru.

Sedangkan hubungan antara pembelajaran geografi terhadap pemahaman wilayah rawan bencana berhubungan secara positif jika pembelajaran geografi berlangsung dengan baik maka pemahaman wilayah rawan bencana akan berpengaruh positif juga. Tetapi kondisi yang terjadi adalah sebaliknya di mana pembelajaran geografi tidak ada hubungannya dengan pemahaman wilayah rawan bencana yang dimiliki oleh peserta didik dikarenakan faktor peristiwa yang sering melanda Kota Bengkulu dan kondisi lingkungan yang ada serta informasi yang diperoleh oleh peserta didik dari kegiatan mengakses internet dan informasi-informasi mengenai bencana yang ada di televisi.

Sedangkan untuk pemahaman wilayah bencana dengan mitigasi bencana bisa dikatakan tidak memiliki hubungan ini terlihat dari hasil Peneliti memperlihatkan kondisi di manatidak adanya hubungan karena dilihat dari hasil nilai soal yang didapat oleh peserta didik di mana hanya 9,9\% peserta didik yang memiliki pemahaman yang baik tentang mitigasi dan sebesar 45,9 \% yang memiliki pemahaman yang cukup. Dari hasil ini sudah dapat memperlihatkan suatu kondisi di mana jika peserta didik memahami wilayah bencana maka peserta didik juga akan memiliki tingkat pengetahuan mitigasi yang lebih baik. Tetapi kondisi yang terjadi di lapangan adalah sebaliknya di mana pemahaman mengenai wilayah bencana peserta didik rendah dan pengetahuan mitigasi peserta didik juga rendah.

Faktoryang mempengaruhi pemahaman mitigasi gempayang dimiliki oleh peserta didik didapat dari faktor lingkungan yang ada disekitar peserta didik baik berupa informasi yang berasal dari media cetak dan informatika.Ini terlihat dari angket di mana peserta didik lebih mengakses melalui media internet dan berita-berita bencana yang ada di televisi.

Ketika peserta didik tahu bahwa mereka tinggal di wilayah rawan bencana maka akan meningkatkan rasa ingin tahu dan rasa ingin belajar peserta didik untuk mengetahui tindakan-tindakan yang harus dilakukan dalam mitigasi bencana baik prabencana, pada saat kejadian bencana dan pascabencana. Prabencana berupa kesiapsiagaan atau upaya memberikan pemahaman pada penduduk untuk mengantisipasi bencana, melalui pemberian informasi, peningkatan kesiagaan kalau terjadi bencana ada langkah-langkah untuk memperkecil resiko bencana.Pada saat kejadian berupa tanggap darurat yaitu upaya yang dilakukan segera pada saat kejadian bencana untuk menanggulangi dampak yang ditimbulkan, terutama berupa penyelamatan korban, harta benda, evakuasi dan pengungsian.Pascabencana berupa pemulihan rehabilitasi dan pembangunan.

Berdasarkan data dan fakta yang terjadi dilapangan memperlihatkan kondisi yang terjadi bahwa peserta didik memiliki pengetahuan yang kurang bahwa wilayah yang mereka diami adalah wilayah rawan bencana, begitu juga dengan pemahaman mitigasi yang dimiliki oleh peserta didik juga kurang seharusnya tingkat pemahaman mitigasi berada pada posisi yang baik untuk dapat memperkecil jumlah korban, baik korban jiwa maupun harta benda. Kondisi ini semakin diperparah dengan pembelajaran geografi yang sangat kurang. 


\section{SIM PULAN}

Dari hasil penelitian yang telah dilaksanakan untuk mengetahui "Peranan Pembelajaran Geografi Dalam Memahami Wilayah Bencana di Kota Bengkulu“ dapat disimpulkan bahwa penelitian yang dilakukan tentang pemahaman peserta didik terhadap kondisi wilayah rawan bencana di Kota Bengkulu memperlihatkan suatu kondisi di mana peserta didik memiliki pemahaman yang rendah akan kondisi rawan bencana yang dimiliki oleh Kota Bengkulu. Hanya 13,93\% peserta didik yang mengetahui dengan baik bahwa Kota Bengkulu adalah rawan bencana.

Kondisi pembelajaran geografi terhadap pemahaman wilayah rawan bencana yang dilihat dari soal untuk pemahaman dan angket untuk kondisi pembelajaran adalah di mana tidak terdapat hubungan yang berarti diantara kedua variabel tersebut. Hasil dari soal pemahaman wilayah rawan bencana di mana peserta didik yang memiliki pemahaman yang baik hanya $9,9 \%$ dan untuk angket yang memiliki kondisi pembelajaran yang baik hanya $14,6 \%$ peserta didik di mana yang lebih berpengaruh adalah faktor lingkungan. Karena pembelajaran yang terjadi belum dilakukan secara meaning full dan materi yang diberikan tentang gempa/ mitigasi bencana hanya menjadi sub pokok materi bukan sebagai pokok utama dari suatu materi.

Kondisi pemahaman wilayah bencana dengan kesiapsiagaan peserta didik dalam mitigasi bencana yang terjadi di Kota Bengkulu seharusnya berpengaruh positif dan saling berpengaruh tetapi pada kondisi dilapangan tidak ada ketekaitan yang berarti antara keduanya.Kalaupun ada keterkaitan diantara keduanya hanya sebesar 0,044. Dari kesimpulan di atas menunjukkan bahwa peranan pembelajaran geografi dalam memahami wilayah bencana memiliki hubungan yang lemah atau dapat dikatakan tidakmemiliki hubungan yang berarti. Kondisi ini diakibatkan dari prosespembelajaran geografi yang kurang baik pada saat penyampaian materi, karena kondisi yang terjadi adalah guru hanya mengandalkan LKS yang berasal dari penerbit.

Penelitian yang telah dilaksanakan di 4 SMA di Kota Bengkulu memperlihatkan suatu kondisi yang harus segera untuk dapat diperbaiki. Temuan ini diharapkan dapat memberikan masukan bagi para guru dan dinas-dinas terkait bahwa begitu sangat memprihatinkannya kondisi pembelajaran geografi yang terjadi. Dengan kondisi seperti ini harus segera dirubah baik mulai dari perencanaan pendidikan yang harus lebih di tingkatkan lagi, fasilitas-fasiltas yang sangat mendukung untuk suatu pelaksanaan pendidikan seharusnya lebih ditingkatkan dalam pengadaannya sehingga guru lebih dapat berinofasi dalam pelaksanaan pembelajaran yang dilakukan dan keyakinan guru dalam menerapkan pembelajaran tentang kebencanaan bukan hanya sekedar idealisme saja.

Kondisi pemahaman tentang wilayah bencana dan kesiapsiagaan peserta didik dalam mitigasi bencana yang harus dimiliki oleh peserta didik yang tinggal diwilayah rawan bencana agar dapat lebih ditingkatkan sehingga ketika terjadi bencana jumlah korban dapat diminimal isir dan dapat lebih siap dalam menghadapi kondisi bencana. Sehinggajumlah korban jiwa dan harta benda dapat di minimalisasi dan dapatkembali pulih dengan cepat setelah bencana terjadi.

\section{DAFTAR PUSTAKA}

Banowati, Eva. (2006). M embangun Pembel ajaran Bermakna. Makalah. Semarang:Seminar Internasional Hispisi. 
Depdiknas.(2006). Petunjuk T eknis Pengembangan Silabus. Jakarta: BSN P

Keputusan Mentri Dalam Negeri RI No. 131 Tahun 2003 Tentang Mitigasi Bencana

Leksono, Suroso Mukti, (2008). Pengembangan Kurikulum Pembelajaran Konservasi.

Peraturan Menteri Pendidikan Nasional Republik Indonesia Nomor 22 tahun 2006 tentang standar isi untuk satuan pendidikan dasar dan menengah

Singarimbun dan Effendi.(1989). M etode Penelitian Survai, Jakarta:LP3ES.

Soedijarto.(1993). M enuju Pendidikan N asional Y ang Relevan dan Bermutu.Cetakan ke-4. Jakarta: Balai Pustaka

Stasiun Meteorologi dan Klimatologi,(2008). Bengkulu

UU No. 24 tahun 2007 tentang Penanggulangan Bencana. 